\title{
Shelf Life Studies of Reduced-Fat Paneer Prepared Using GDL as an Acidulant
}

\author{
Mamata Chaudhary*, Suneeta Pinto, Preeti Paul and R. Yashvantha \\ Dairy Technology Department, SMC College of Dairy Science, Anand Agricultural \\ University, Anand (Gujarat) 388 110, India \\ *Corresponding author
}

\section{A B S T R A C T}

\section{Keywords}

Reduced-fat paneer, Shelf-life, Sensory characteristics, Acidity, Free fatty acids, Tyrosine value, Textural properties

Article Info

Accepted:

15 May 2019

Available Online:

10 June 2019

\begin{abstract}
In the present study, changes in compositional, physico-chemical, sensory and microbial properties of reduced-fat paneer (RFP) vacuum packed in laminated pouches was evaluated for its shelf-life at refrigerated temperature $\left(7 \pm 1^{\circ} \mathrm{C}\right)$. Control paneer $(\mathrm{CP})$ was prepared from standardized milk ( $4.5 \%$ fat $/ 8.5 \%$ MSNF). The sensory characteristics, acidity (\% LA), free fatty acid (\% oleic acid), tyrosine content $(\mathrm{mg} / 100 \mathrm{~g})$, textural properties and microbial quality (standard plate count, yeast and mold count and coliform count) of stored samples viz. RFP and CP were monitored at an interval of every $4^{\text {th }}$ day when stored at $7 \pm 1{ }^{\circ} \mathrm{C}$. During storage there was a significant $(\mathrm{P}<0.05)$ increase in acidity, free fatty acid and tyrosine content. The hardness, springiness, chewiness and gumminess values decreased significantly $(\mathrm{P}<0.05)$ during storage. However, no significant $(\mathrm{P}>0.05)$ effect was found on cohesiveness values during storage. There was a significant $(\mathrm{P}<0.05)$ increase in SPC and yeast and mold count during storage. The shelf life of reduced-fat paneer was estimated to be 16 days when stored at $7 \pm 1{ }^{\circ} \mathrm{C}$ in $12 \mu$ polyester $+50 \mu$ LD/LLDPE laminated pouches under vacuum compared to 12 days for control paneer prepared from standardized milk.
\end{abstract}

\section{Introduction}

Paneer is a heat and acid coagulated traditional Indian dairy product. India is a country with a substantial number of vegetarian people. It is a good source of high quality animal protein for vegetarians. The global paneer market is expected to reach a value of Rs. 1281 billion by 2023, at a projected CAGR of $14.5 \%$ during 2018-2023 (IMARC, 2018). Conventional paneer is rich in fat content. The average fat content of paneer is $23-26 \%$. Low-fat or reduced-fat products are formulated or designed so as to meet the dietary requirements of obese, persons at risk of cardiovascular diseases, diabetics, and persons on weight management diets (Sandrou and Arvanitoyannis, 2003). Glucono- $\delta$-lactone is an acidulant often abbreviated to GDL. GDL hydrolyses in water to form gluconic acid. GDL is a natural component of many foods. GDL is a non- 
agricultural additive; it can be produced in a non-synthetic way. GDL is readily soluble in water and is used in a range of applications. It is thought to be one of the best acids to reduce $\mathrm{pH}$ without giving an excessive acidic flavour profile of the food product (Lucey and Kelly, 1994). It reduces the $\mathrm{pH}$ and helps to preserve the food from enzymes and microorganisms deterioration. It is commonly used and preferred to make silken soft tofu (Guo and Ono, 2005). The hydrocolloids have also been widely used in milk and milk products. Hydrocolloids have been used to improve the body and texture of the cheese, chhana, paneer to reduce the loss of solids in whey (Bhadekar et al., 2008). Murtaza et al., (2017) prepared low-fat cheddar cheese from 2.0 per cent fat buffalo milk by adding xanthan gum and guar gums individually @ 0.15,0.30 and 0.45 per cent. They concluded that hydrocolloids gums particularly guar gum can effectively be used @ 0.45 per cent to produce low-fat cheddar cheese with functional, textural and sensory characteristics comparable to full fat product. Hence, they recommended that defects in quality and acceptability of low-fat cheeses can be overcome by incorporating hydrocolloid gums as fat replacers without any adverse effects. Shendi (2017) used guar gum as fat replacer for manufacture of low-fat Iranian White Cheese without side effects.

Acidity, FFA and tyrosine value are the important chemical characteristics of paneer which help to monitor keeping quality during storage of paneer. The behavior of paneer as similar to other dairy/food products during storage is critical for its commercial success. Paneer should have enough shelf-life during storage, to make the product commercially feasible. The heat treatment of milk is more than enough to destroy all the pathogenic and spoilage microorganisms. Spoilage occurs due to contamination either during or after manufacturing of product. The shelf-life of paneer is reported to be under refrigeration for only six days, although its freshness is lost within three days; while at room temperature, paneer kept not well for more than one day (Bhattacharya et al., 1971). However, no reports are available in literature on shelf life studies of reduced-fat paneer prepared using GDL as an acidulant. Tavakolipour et al., (2014) reported that Iranian white cheese prepared using GDL increases shelf life by preventing the growth of microorganisms due to reduced $\mathrm{pH}$. Hence, this experiment was planned and conducted to evaluate the shelf life of reduced fat paneer prepared using GDL as an acidulant in comparison with control paneer prepared from standardized milk using citric acid as a coagulant.

\section{Materials and Methods}

\section{Raw material}

For the preparation of reduced-fat paneer (RFP) full cream milk $(6.1 \%$ fat, $9.1 \%$ MSNF) was collected from Vidya Dairy, Anand. Skim milk (0.2\% fat, 9.1\% MSNF) was collected from Anubhav dairy, Anand. For making control paneer standardized milk (4.5\% fat and $8.5 \% \mathrm{MSNF}$ ) was collected from Vidya dairy, Anand. Carboxymethyl cellulose and citric acid of Loba-chemicals private Ltd., Mumbai were used. Glucono delta-lactone (GDL) of Roquette India, Pvt. Ltd., Mumbai used as an acidulant in RFP.

\section{Preparation of paneer}

Reduced-fat paneer (RFP) was manufactured from $2.0 \mathrm{~kg}$ milk standardized to $1.0 \%$ fat. Six hundred $\mathrm{mg}$ carboxymethyl cellulose (CMC) per $\mathrm{kg}$ of milk (w/w of milk) was accurately weighed and made into a paste by adding a small amount (about 100 times its weight) of lukewarm milk. The hydrocolloid paste was added to milk at $40-45^{\circ} \mathrm{C}$ and mixed thoroughly. The milk was heated to $90^{\circ} \mathrm{C}$ for 
5 min and subsequently cooled to $80^{\circ} \mathrm{C}$. Glucono delta-lactone in the form of a $2.0 \%$ solution was used as an acidulant at $80^{\circ} \mathrm{C}$. The acidulant was added slowly to the milk with slow stirring until a coagulum and clear whey separated out. The coagulum was allowed to settle for $5 \mathrm{~min}$ and the whey was drained through a muslin cloth. During this time, the temperature of whey was maintained above $75^{\circ} \mathrm{C}$. The coagulum was then collected and filled in a rectangular shaped sterilized stainless steel paneer hoop lined with a clean sterile muslin cloth. The coagulum was pressed for $20 \mathrm{~min}$ by applying a pressure of 2 to $2.5 \mathrm{~kg} / \mathrm{cm}^{2}$. The pressed block was removed from the hoop and immersed in pasteurized chilled water $\left(4\right.$ to $\left.6^{\circ} \mathrm{C}\right)$ for 2 hours. The block of paneer removed from chilled water was allowing the water to drain off for $5 \mathrm{~min}$. Paneer was vacuum packed in $12 \mu$ polyester $+50 \mu \mathrm{LD} / \mathrm{LLDPE}$ laminated pouches and stored at refrigeration temperature $7 \pm 1^{\circ} \mathrm{C}$. Control paneer (CP) was prepared from milk standardized to $4.5 \%$ fat and $8.5 \%$ MSNF using the procedure outlined by Aneja et al., (2002) using $1.0 \%$ citric acid as a coagulant.

The acidity (\% LA), free fatty acid (FFA) value expressed as \% oleic acid, tyrosine content $(\mathrm{mg} / 100 \mathrm{~g})$, sensory characteristics, textural properties and microbial quality (standard plate count, yeast and mold count and coliform count) of stored samples of paneer were monitored at every $4^{\text {th }}$ day of storage at refrigeration temperature $\left(7 \pm 1^{\circ} \mathrm{C}\right)$ until the product was rejected on, basis of sensory acceptability or mold growth appear on the surface of the product.

\section{Sensory evaluation}

Each block of paneer was cut into approximately $25 \mathrm{~g}$ rectangular pieces. The paneer samples were tempered to $10 \pm 2^{\circ} \mathrm{C}$ before judging. The sensory panel $(n=9)$ was composed of staff members and post graduate students working in the institution. The paneer samples were evaluated using 100 point scale as described in Indian Standards (IS: 15346, 2003).

\section{Physico-chemical analysis}

Moisture and titratable acidity content in paneer was determined by according to IS: 10484 (1983). Free fatty acid (FFA) of paneer samples was determined by the method described by Koniecko (1979). Tyrosine value of paneer samples were estimated by the method as described by Lowry et al., (1951) with some modification

\section{Textural analysis}

Compression testing of paneer samples was done with Lloyd Instrument, Hampshire, UK (Model No. 01/2962) using $5 \mathrm{KN}$ load-cells which moved at a speed of $20 \mathrm{~mm} / \mathrm{min}$. The paneer samples were taken for texture measurement after tempering the same at $10 \pm 1^{\circ} \mathrm{C}$ for $\mathrm{h}$. All the textural measurements were conducted in a room maintained at $23 \pm 1^{\circ} \mathrm{C}$ temperature and $65 \pm 1 \% \mathrm{RH}$. Cubic samples of the experimental paneer, with edges of $2.00 \pm 0.06 \mathrm{~cm}$, were placed in the compression support plate in such a manner that fibers were oriented perpendicular to the cylindrical compression anvil. The cubic samples were compressed up to $70 \%$ of their initial size. Five cubic samples were used for each experimental paneer under study and the average value of these readings was reported.

\section{Microbiological analysis}

For microbial analysis 11 grams of each of the paneer sample was aseptically weighed and transferred into $99 \mathrm{ml}$ sterile citrate buffer flask. Further dilutions were prepared using 9 $\mathrm{ml}$ sterile citrate buffer blanks. Suitable dilutions (selected based on preliminary study 
conducted) of each sample was transferred $(1.0 \mathrm{ml})$ aseptically into sterile Petri plates. For SPC, plates were prepared using standard plate count agar as per the procedure described in IS: 5402 (1969). For coliform count plates were prepared using VRBA as per the procedure described in IS: 5401 (1969). For yeast and mold count plates were prepared using PDA as per the procedure described in IS: 5403 (1969).

\section{Statistical analysis}

Statistical analysis of data was carried out using Factorial Completely Randomized Design (FCRD).

\section{Results and Discussion}

\section{Effect of storage period on sensory} characteristics

The results related to flavour score, body and texture score, colour and appearance score and total score of both control paneer $(\mathrm{CP})$ and reduced-fat paneer (RFP) during storage present in Table 1.

For consumers flavour has a great impact for choice and acceptability. Fresh $\mathrm{CP}$ had a flavour score of 44.40 (out of 50) which was found to decrease significantly $(\mathrm{P}<0.05)$ to 39.23 after storage period of 12 days and it further decreased significantly $(\mathrm{P}<0.05)$ to 25.47 on $16^{\text {th }}$ day of storage. The product was acceptable till 12 days and at $16^{\text {th }}$ day, the product was not acceptable due to development of bitter taste and stale offflavour in the product. In case of RFP, the flavour score decreased from the initial value of 42.10 decreased to 35.03 (on the $16^{\text {th }}$ day) and on $20^{\text {th }}$ day the judging panel rejected the sample due to development of bitter taste and stale off-flavour in the product. Statistical analysis revealed that type of paneer as well as storage period had significant $(\mathrm{P}<0.05)$ effect on the flavour score of paneer. The interaction between type of paneer (T) and storage period $(\mathrm{P})$ was found to be statistically significant $(\mathrm{P}<0.05)$ for changes in flavour score of paneer samples over the storage period.

The initial body and texture score of $\mathrm{CP}$ and RFP were 31.80 and 30.83 respectively. The body and texture score of CP and RFP paneer during storage tend to decrease significantly $(\mathrm{P}<0.05)$ with the increase in storage period. The statistical analysis revealed that type of paneer had non-significant $(\mathrm{P}>0.05)$ effect on the body and texture score. The storage period had significant $(\mathrm{P}<0.05)$ effect on body and texture score. The interaction between type of paneer $(\mathrm{T})$ and storage period $(\mathrm{P})$ was found to be statistically non-significant $(\mathrm{P}>0.05)$.

The initial colour and appearance score of $\mathrm{CP}$ and RFP were 8.10 and 8.33 respectively. The colour and appearance score of RFP was higher as compared to CP. This may be due to lower fat content in developed paneer that paneer had more white in colour as compared to control paneer. The statistical analysis revealed that type of paneer as well as storage period had significant $(\mathrm{P}<0.05)$ effect on the colour and appearance score. The interaction between type of paneer $(\mathrm{T})$ and storage period (P) was found to be statistically nonsignificant $(\mathrm{P}>0.05)$ on colour and appearance score.

The initial total score of $\mathrm{CP}$ and RFP were 89.30 and 86.27 respectively. The total score of CP and RFP was decreased with increases storage period. The type of paneer showed non-significant $(\mathrm{P}>0.05)$ difference in total score. The storage period showed significant $(\mathrm{P}<0.05)$ difference in total score. The interaction between type of paneer (T) and storage period $(\mathrm{P})$ was statistically significant $(\mathrm{P}<0.05)$ for changes in total score. The observed reduction in total score of paneer 
could partly ascribed to the development of change in flavour owing to development of bitter after taste and dull colour and appearance to some extent. The overall sensory scores indicate a shelf life of 12 days at refrigeration temperature for $\mathrm{CP}$ and 16 days at refrigeration temperature for RFP.

\section{Effect of storage period on physico- chemical properties}

Changes in selected physico-chemical properties of RFP and CP viz. moisture, acidity, free fatty acid and tyrosine content during storage at $7 \pm 1^{\circ} \mathrm{C}$ is presented in Table 2.

\section{Moisture}

As seen from Table 2 the moisture of paneer decreased slightly with increase in storage period. Fresh CP had moisture of $53.93 \pm 1.08$ $\%$ which decreased non-significantly $(\mathrm{P}>0.05)$ to $51.93 \pm 1.44$ after 16 days of refrigerated storage.

Fresh RFP had moisture 64.10 $\pm 1.10 \%$ which decreased non-significantly $(\mathrm{P}>0.05)$ to $62.73 \pm 1.01$ after 12 days, $62.50 \pm 1.25$ after 16 days of storage at refrigerated temperature. The type of paneer showed significant $(\mathrm{P}<0.05)$ effect on moisture. The storage period showed non-significant $(\mathrm{P}>0.05)$ effect on moisture.

The interaction between type of paneer and storage period showed non-significant ( $>$ $>0.05)$ effect. Here, no significance difference observed in moisture content. Since products were packed in high barrier laminates under vacuum. However, no research has been reported in literature on the changes in moisture content of reduced-fat paneer prepared by using GDL as an acidulant in combination with $\mathrm{CMC}$ during storage for comparison.

\section{Acidity}

As seen from Table 2 the acidity of paneer increased with increase in storage period. Fresh CP had acidity of $0.454 \pm 0.01 \%$ LA which increased significantly $(\mathrm{P}<0.05)$ to $0.527 \pm 0.02 \%$ LA after 12 days, $0.610 \pm 0.03 \%$ LA after 16 days of refrigerated storage. Fresh RFP had acidity $0.470 \pm 0.01 \%$ LA which increased significantly $(\mathrm{P}<0.05)$ to $0.513 \pm 0.02 \%$ LA after 12 days, $0.567 \pm 0.02 \%$ LA after 16 days of storage at refrigerated temperature. The type of paneer showed nonsignificant $(\mathrm{P}>0.05)$ effect on acidity. The storage period showed significant $(\mathrm{P}<0.05)$ effect. The interaction between type of paneer and storage period showed significant $(\mathrm{P}<0.05)$ effect.

The titratable acidity (\% LA) is an important degradative chemical change which can occur in paneer during storage. The level of the acidity developed may also be used to specify the extent of microbial fermentation. The influence of storage period on acidity is a normal biochemical process in dairy products which might be the result of additional fragmentation of proteins and degradation of lactose and also because of shift of minerals from serum to colloidal state.

The results for acidity obtained in this study are higher than those observed by Roy (2016) who reported that the titratable acidity of reduced-fat paneer samples prepared from $2.5 \%$ fat milk using 2.0 per cent citric acid solution as a coagulant increased from 0.24 to $0.27 \%$ LA after 12 days in LDPE (Low Density Poly-ethylene) package and from 0.24 to $0.28 \%$ LA after 15 days in LP (Laminated Pouch) package during storage.

The results for acidity obtained in this study are much lower than the observed by Gediya (2014) who reported that the acidity of paneer increased significantly $(\mathrm{P}<0.05)$ from 
$0.765 \pm 0.00 \%$ LA to $0.973 \pm 0.02 \%$ LA after 16 days of refrigerated storage. The increase in initial acidity could be because of use of different type of coagulant i.e. Amla juice used in her study. The observed acidity of paneer samples are within in the range reported by Patel (2014) who observed that that titratable acidity of paneer samples treated with Na-Sorbate was found to be $0.484 \pm 0.013$ on $0^{\text {th }}$ day and it increased to $0.558 \pm 0.009$ on $15^{\text {th }}$ day of storage. Ranmode (2010) also reported that in case of control sample showed gradual increase in acidity which reached to $0.534 \%$ of lactic acid on $6^{\text {th }}$ day. In case of samples treated with nisin had acidity remained stable upto $6^{\text {th }}$ day and thereafter increased drastically. It reached to $0.546 \%$ at the end of shelf life. However, no research has been reported in literature on the changes in acidity of reduced-fat paneer prepared by using GDL as an acidulant in combination with CMC during storage for comparison.

\section{Free fatty acid content}

As seen from Table 2 the initial free fatty acids content of CP was higher as compared to RFP. The FFA value of paneer increased significantly $(\mathrm{P}<0.05)$ with increase in storage period. Fresh CP had FFA value $0.183 \pm 0.009$ $\%$ oleic acid which increased significantly $(\mathrm{P}<0.05)$ to $0.236 \pm 0.008 \%$ oleic acid after 12 days, $0.263 \pm 0.014 \%$ oleic acid after 16 days of refrigerated storage. Fresh RFP had FFA $0.115 \pm 0.009 \%$ oleic acid which increased significantly $(\mathrm{P}<0.05)$ to $0.201 \pm 0.016 \%$ oleic acid after 16 days of storage at refrigerated temperature.

The type of paneer showed significant $(\mathrm{P}<0.05)$ effect on FFA content. The storage period showed significant $(\mathrm{P}<0.05)$ effect. The interaction between type of paneer and storage period showed non-significant $(\mathrm{P}>0.05)$ effect.
Roy (2016) reported that the FFA content $(\mu$ equivalent/g) in reduced-fat paneer samples increased during storage from 2.56 to 3.46 in LDPE package after 12 days and from 2.56 to 3.37 in laminated package after 15 days. The results obtained in this part of study are within the range reported by Khatkar et al., (2017) and Patel (2014). Khatkar et al., (2017) reported that the free fatty acid (\% oleic acid) of control sample increased from an initial 0.175 to 0.517 in 10 days, to 0.491 in 8 days and to 0.541 in 5 days when packed with MP, NP and LDPE, respectively. Patel (2014) reported that FFA (\% oleic acid) of control paneer was 0.050 on $0^{\text {th }}$ day which increased to 0.167 on $15^{\text {th }}$ day of storage and for sample with Na-sorbate had 0.037 on $0^{\text {th }}$ day and increased to 0.095 on $15^{\text {th }}$ day of storage. The differences in FFA value of paneer samples reported by these authors could be due to difference in type and quality of products used and differences in processing conditions. However, no research has been reported in literature on the changes in FFA content of reduced-fat paneer prepared by using GDL as an acidulant in combination with $\mathrm{CMC}$ during storage for comparison.

\section{Tyrosine content}

As seen from Table 2 the initial tyrosine content of CP was lower as compared to RFP. The tyrosine content of paneer increased with increase in storage period. Fresh $\mathrm{CP}$ had tyrosine content $10.080 \pm 0.596 \mathrm{mg} / 100 \mathrm{~g}$ which increased significantly $(\mathrm{P}<0.05)$ to $34.981 \pm 0.665 \mathrm{mg} / 100 \mathrm{~g}$ after 12 days, $41.966 \pm 0.411 \mathrm{mg} / 100 \mathrm{~g}$ after 16 days of refrigerated storage. Fresh RFP had tyrosine content $27.299 \pm 0.759 \mathrm{mg} / 100 \mathrm{~g}$ which increased significantly $\quad(\mathrm{P}<0.05) \quad$ to $49.293 \pm 0.417 \mathrm{mg} / 100 \mathrm{~g}$ after 16 days of storage at refrigerated temperature. The type of paneer showed significant $(\mathrm{P}<0.05)$ effect on tyrosine content. The storage period showed significant $(\mathrm{P}<0.05) \quad$ effect. The 
interaction between type of paneer and storage period showed significant $(\mathrm{P}<0.05)$ effect. The RFP had higher values of tyrosine content as compared to CP. This may be due to presence of higher moisture content in RFP.

The values obtained for tyrosine content are in accordance to those reported in literature. Khatkar et al., (2017) reported that tyrosine content $(\mathrm{mg} / 100 \mathrm{~g})$ of control sample increased highly from an initial 12.192 to 28.642 in 10 days, to 32.531 in 8 days and to 39.336 in 5 days when packed with MP, NP and LDPE, respectively. Joseph (2016) observed that the initial average value of tyrosine content $(\mathrm{mg} / 100 \mathrm{ml})$ of control paneer was $5.29 \mathrm{mg} / 100 \mathrm{~g}$ and for lemongrass added paneer sample was 3.64.

In the case of control sample, the tyrosine value increased to 25.59 after 18 days of storage and for lemongrass added sample the final value was observed to be 23.38 , after 23 days of storage. The differences in tyrosine content of paneer samples reported by these authors could be due to difference in type and quality of products used and differences in processing conditions.

However, no research has been reported in literature on the changes in tyrosine content of reduced-fat paneer prepared by using GDL as an acidulant in combination with $\mathrm{CMC}$ during storage for comparison.

\section{Effect of storage period on textural properties}

Textural properties play an important role in the quality of paneer. The texture of paneer depends upon the status of components and the temperature of storage. The changes in textural properties viz. hardness, cohesiveness, chewiness, springiness and gumminess were showed in Table 3.

\section{Hardness}

The results indicated that the initial hardness of CP was lower than RFP (Table 3). The hardness of paneer samples decreased significantly $(\mathrm{P}<0.05)$ with increase in storage period. Fresh $\mathrm{CP}$ had hardness $15.75 \pm 1.66 \mathrm{~N}$ which decreased significantly $(\mathrm{P}<0.05)$ to $14.31 \pm 1.59 \mathrm{~N}$ after 12 days, $13.41 \pm 1.83 \mathrm{~N}$ after 16 days of refrigerated storage. Fresh RFP had hardness $18.89 \pm 1.28 \mathrm{~N}$ which decreased significantly $(\mathrm{P}<0.05)$ to $15.80 \pm 1.45 \mathrm{~N}$ after 16 days of storage at refrigerated temperature. The type of paneer showed significant $(\mathrm{P}<0.05)$ effect on hardness. The storage period showed significant $(\mathrm{P}<0.05)$ effect. The interaction between type of paneer and storage period showed non-significant $(\mathrm{P}>0.05)$ effect.

Joseph (2016) also reported similar observation that hardness of lemongrass added paneer decreased with increased storage period. Hardness of lemongrass added paneer was $21.30 \pm 0.23$ on $0^{\text {th }}$ day, which decreased to $16.78 \pm 0.21$ after 23 days of storage at refrigeration temperature.

\section{Cohesiveness}

The results indicated that the initial cohesiveness of CP was lower than RFP (Table 3). The cohesiveness of paneer samples decreased non-significantly $(\mathrm{P}>0.05)$ with increase in storage period. Fresh $\mathrm{CP}$ had cohesiveness $0.4684 \pm 0.0244$ which decreased non-significantly $(\mathrm{P}>0.05)$ to $0.4518 \pm 0.0444$ after 12 days, $0.4457 \pm 0.0327$ after 16 days of refrigerated storage. Fresh RFP had cohesiveness $0.5227 \pm 0.0327$ which decreased non-significantly $(\mathrm{P}>0.05)$ to $0.4558 \pm 0.0254$ after 16 days of storage at refrigerated temperature. The type of paneer showed significant $(\mathrm{P}<0.05)$ effect on cohesiveness. The storage period showed non-significant $(\mathrm{P}>0.05)$ effect. 
Table.1 Changes in sensory characteristics of RFP and CP during storage at $7 \pm 1^{\circ} \mathrm{C}$

\begin{tabular}{|c|c|c|c|c|c|c|}
\hline \multirow[t]{2}{*}{ Type of paneer $(\mathbf{T})$} & \multicolumn{5}{|c|}{ Storage period in days $(\mathrm{P})$} & \multirow[t]{2}{*}{ Average for Treatment ( $T$ ) } \\
\hline & 0 & 4 & 8 & 12 & 16 & \\
\hline \multicolumn{7}{|l|}{ Flavour score (max. 50) } \\
\hline RFP & $42.10 \pm 0.66$ & $41.80 \pm 0.82$ & $40.67 \pm 0.58$ & $39.77 \pm 0.68$ & $35.03 \pm 0.45$ & 39.87 \\
\hline Average for Period(P) & 43.25 & 42.88 & 41.50 & 39.50 & 34.25 & \\
\hline \multicolumn{7}{|c|}{ Body and Texture score (max. 35) } \\
\hline $\mathbf{C P}$ & $31.80 \pm 0.82$ & $31.63 \pm 1.18$ & $31.13 \pm 0.99$ & $30.50 \pm 1.32$ & $26.57 \pm 1.23$ & 30.33 \\
\hline RFP & $30.83 \pm 1.26$ & $30.53 \pm 1.29$ & $30.27 \pm 1.12$ & $29.77 \pm 0.93$ & $27.53 \pm 1.01$ & 29.79 \\
\hline Average for Period(P) & 31.32 & 31.08 & 30.70 & 30.13 & 27.05 & \\
\hline Average for Period(P) & 8.22 & 8.13 & 7.93 & 7.76 & 7.28 & \\
\hline \multicolumn{7}{|c|}{$\mathrm{CD}(0.05) \mathrm{T}=0.223 ; \mathrm{P}=0.353 ; \mathrm{TxP}=\mathrm{NS}$} \\
\hline \multicolumn{7}{|c|}{ Total score* $(\max .100) * 5$ out of 5 marks allotted for packaging } \\
\hline $\mathbf{C P}$ & $89.30 \pm 0.70$ & $88.63 \pm 1.97$ & $86.35 \pm 1.18$ & $82.40 \pm 1.39$ & $64.00 \pm 0.95$ & 82.13 \\
\hline RFP & $86.27 \pm 1.66$ & $85.55 \pm 1.79$ & $83.92 \pm 0.98$ & $82.38 \pm 0.63$ & $75.16 \pm 1.10$ & 82.65 \\
\hline Average for Period(P) & 87.78 & 87.09 & 85.13 & 82.39 & 69.58 & \\
\hline \multicolumn{7}{|c|}{$\mathrm{CD}(0.05) \mathrm{T}=\mathrm{NS} ; \mathrm{P}=1.576 ; \mathrm{TxP}=2.228$} \\
\hline
\end{tabular}


Table. 2 Changes in physico-chemical properties of RFP and CP during storage at $7 \pm 1^{0} \mathrm{C}$

\begin{tabular}{|c|c|c|c|c|c|c|}
\hline \multirow[t]{2}{*}{ Type of paneer (T) } & \multicolumn{5}{|c|}{ Storage period in days $(\mathrm{P})$} & \multirow[t]{2}{*}{ Average for Treatment $(\mathbf{T})$} \\
\hline & 0 & 4 & 8 & 12 & 16 & \\
\hline \multicolumn{7}{|l|}{ Moisture (\%) } \\
\hline RFP & $64.10 \pm 1.10$ & $63.87 \pm 1.40$ & $63.27 \pm 0.92$ & $62.73 \pm 1.01$ & $62.50 \pm 1.25$ & 63.29 \\
\hline Average for Period(P) & 59.02 & 58.72 & 58.08 & 57.45 & 57.22 & \\
\hline $\mathbf{C P}$ & $0.454 \pm 0.01$ & $0.471 \pm 0.01$ & $0.494 \pm 0.01$ & $0.527 \pm 0.02$ & $0.610 \pm 0.03$ & 0.511 \\
\hline RFP & $0.470 \pm 0.01$ & $0.477 \pm 0.01$ & $0.490 \pm 0.02$ & $0.513 \pm 0.02$ & $0.567 \pm 0.02$ & 0.503 \\
\hline Average for Period(P) & 0.462 & 0.474 & 0.492 & 0.520 & 0.588 & \\
\hline \multicolumn{7}{|c|}{$\mathrm{CD}(0.05) \mathrm{T}=\mathrm{NS} ; \mathrm{P}=0.019 ; \mathrm{TxP}=0.027$} \\
\hline Average for Period(P) & 0.149 & 0.169 & 0.187 & 0.208 & 0.232 & \\
\hline \multicolumn{7}{|c|}{$\mathrm{CD}(0.05) \mathrm{T}=0.009 ; \mathrm{P}=0.014 ; \mathrm{TxP}=\mathrm{NS}$} \\
\hline \multicolumn{7}{|c|}{ Tyrosine content (mg/100g) } \\
\hline $\mathbf{C P}$ & $10.080 \pm 0.596$ & $22.961 \pm 0.413$ & $30.347 \pm 0.760$ & $34.981 \pm 0.665$ & $41.966 \pm 0.411$ & 28.060 \\
\hline RFP & $27.299 \pm 0.759$ & $31.150 \pm 0.949$ & $40.820 \pm 0.852$ & $44.276 \pm 0.968$ & $49.293 \pm 0.417$ & 38.568 \\
\hline Average for Period(P) & 18.673 & 27.055 & 35.584 & 39.628 & 45.630 & \\
\hline \multicolumn{7}{|c|}{$\mathrm{CD}(0.05) \mathrm{T}=0.540 ; \mathrm{P}=0.854 ; \mathrm{TxP}=1.208$} \\
\hline
\end{tabular}


Table.3 Changes in textural properties of RFP and CP during storage at $7 \pm 1^{0} \mathrm{C}$

\begin{tabular}{|c|c|c|c|c|c|c|}
\hline \multirow[t]{2}{*}{ Type of paneer (T) } & \multicolumn{5}{|c|}{ Storage period in days $(P)$} & \multirow{2}{*}{$\begin{array}{c}\text { Average for } \\
\text { Treatment (T) }\end{array}$} \\
\hline & 0 & 4 & 8 & 12 & 16 & \\
\hline \multicolumn{7}{|l|}{ Hardness (N) } \\
\hline $\mathbf{C P}$ & $15.75 \pm 1.66$ & $15.65 \pm 0.68$ & $15.06 \pm 0.89$ & $14.31 \pm 1.59$ & $13.41 \pm 1.83$ & 14.84 \\
\hline Average for Period(P) & 17.32 & 16.82 & 16.08 & 15.32 & 14.60 & \\
\hline \multicolumn{7}{|c|}{$\mathrm{CD}(0.05) \mathrm{T}=1.191 ; \mathrm{P}=1.883 ; \mathrm{TxP}=\mathrm{NS}$} \\
\hline $\mathbf{C P}$ & $0.4684 \pm 0.0244$ & $0.4570 \pm 0.0363$ & $0.4543 \pm 0.0207$ & $0.4518 \pm 0.0444$ & $0.4457 \pm 0.0327$ & 0.4555 \\
\hline RFP & $0.5227 \pm 0.0327$ & $0.4852 \pm 0.0218$ & $0.4796 \pm 0.0151$ & $0.4770 \pm 0.0409$ & $0.4558 \pm 0.0254$ & 0.4841 \\
\hline Average for Period(P) & 0.4956 & 0.4711 & 0.4670 & 0.4644 & 0.4508 & \\
\hline \multicolumn{7}{|c|}{$\mathrm{CD}(0.05) \mathrm{T}=0.023 ; \mathrm{P}=\mathrm{NS} ; \mathrm{TxP}=\mathrm{NS}$} \\
\hline \multicolumn{7}{|l|}{ Chewiness (Nmm) } \\
\hline \multicolumn{7}{|l|}{ Springiness (mm) } \\
\hline $\mathbf{C P}$ & $6.245 \pm 0.128$ & $6.196 \pm 0.115$ & $6.030 \pm 0.088$ & $5.863 \pm 0.145$ & $5.859 \pm 0.109$ & 6.039 \\
\hline RFP & $6.654 \pm 0.112$ & $6.623 \pm 0.131$ & $6.522 \pm 0.122$ & $6.507 \pm 0.093$ & $6.367 \pm 0.174$ & 6.535 \\
\hline Average for Period(P) & 6.450 & 6.409 & 6.276 & 6.185 & 6.113 & \\
\hline \multicolumn{7}{|c|}{$\mathrm{CD}(0.05) \mathrm{T}=0.094 ; \mathrm{P}=0.149 ; \mathrm{TxP}=\mathrm{NS}$} \\
\hline \multicolumn{7}{|l|}{ Gumminess (N) } \\
\hline $\mathbf{C P}$ & $7.194 \pm 0.611$ & $7.164 \pm 0.602$ & $6.825 \pm 0.416$ & $6.498 \pm 0.451$ & $6.193 \pm 0.557$ & 6.775 \\
\hline RFP & $8.967 \pm 0.448$ & $8.082 \pm 0.633$ & $7.359 \pm 0.462$ & $6.518 \pm 0.465$ & $6.266 \pm 0.618$ & 7.039 \\
\hline Average for Period(P) & 7.881 & 7.423 & 6.892 & 6.308 & 6.029 & \\
\hline \multicolumn{7}{|c|}{$\mathrm{CD}(0.05) \mathrm{T}=0.406 ; \mathrm{P}=0.641 ; \mathrm{TxP}=\mathrm{NS}$} \\
\hline
\end{tabular}


Table.4 Changes in microbial quality of RFP and CP during storage at $7 \pm 1^{\circ} \mathrm{C}$

\begin{tabular}{|c|c|c|c|c|c|c|}
\hline \multirow[t]{2}{*}{ Type of paneer $(T)$} & \multicolumn{5}{|c|}{ Storage period in days $(\mathrm{P})$} & \multirow[t]{2}{*}{ Average for Treatment (T) } \\
\hline & 0 & 4 & 8 & 12 & 16 & \\
\hline \multicolumn{7}{|c|}{ Standard plate count $\left(\log _{10} \mathrm{cfu} / \mathrm{g}\right)$} \\
\hline $\mathbf{C P}$ & $3.50 \pm 0.19$ & $3.98 \pm 0.08$ & $4.79 \pm 0.05$ & $5.12 \pm 0.03$ & $5.41 \pm 0.01$ & 4.56 \\
\hline RFP & $3.33 \pm 0.21$ & $3.89 \pm 0.08$ & $4.68 \pm 0.07$ & $5.03 \pm 0.02$ & $5.32 \pm 0.01$ & 4.45 \\
\hline Average for Period(P) & 3.41 & 3.93 & 4.74 & 5.08 & 5.37 & \\
\hline \multicolumn{7}{|c|}{$\mathrm{CD}(0.05) \mathrm{T}=0.078 ; \mathrm{P}=0.123 ; \mathrm{TxP}=\mathrm{NS}$} \\
\hline \multicolumn{7}{|c|}{ Yeast and Mold count (cfu per g) } \\
\hline $\mathbf{C P}$ & $0.00 \pm 0.00$ & $1.67 \pm 1.15$ & $3.83 \pm 1.04$ & $9.17 \pm 1.04$ & $17.00 \pm 2.65$ & 6.33 \\
\hline RFP & $0.00 \pm 0.00$ & $1.33 \pm 0.58$ & $2.67 \pm 1.53$ & $4.67 \pm 1.15$ & $10.33 \pm 1.53$ & 3.80 \\
\hline Average for Period(P) & 0.00 & 1.50 & 3.25 & 6.92 & 13.67 & \\
\hline \multicolumn{7}{|c|}{$\mathrm{CD}(0.05) \mathrm{T}=0.988 ; \mathrm{P}=1.563 ; \mathrm{TxP}=2.210$} \\
\hline
\end{tabular}


The interaction between type of paneer and storage period showed non-significant $(\mathrm{P}>0.05)$ effect. Joseph (2016) also reported that cohesiveness of lemongrass added paneer decreased with increased storage period. Cohesiveness of lemongrass added paneer was $0.47 \pm 0.07$ on $0^{\text {th }}$ day, which decreased to $0.35 \pm 0.01$ after 23 days of storage at refrigeration temperature. Thus, results are in agreement with those reported in literature.

\section{Chewiness}

The results indicated that the initial chewiness of CP was lower than RFP (Table 3). The chewiness of paneer samples decreased significantly $(\mathrm{P}<0.05)$ with increase in storage period. Fresh $\mathrm{CP}$ had chewiness 42.358 $\pm 2.358 \quad \mathrm{Nmm}$ which decreased significantly $(\mathrm{P}<0.05)$ to $40.669 \pm 1.601 \mathrm{Nmm}$ after 12 days, $38.898 \pm 2.816$ after 16 days of refrigerated storage. Fresh RFP had chewiness 58.693 \pm 1.291 which decreased significantly $(\mathrm{P}<0.05)$ to $41.561 \pm 2.208 \mathrm{Nmm}$ after 16 days of storage at refrigerated temperature. The type of paneer showed significant $(\mathrm{P}<0.05)$ effect on chewiness. The storage period showed significant $(\mathrm{P}<0.05)$ effect. The interaction between type of paneer and storage period showed significant $(\mathrm{P}<0.05)$ effect on chewiness. Joseph (2016) also observed that chewiness of lemongrass added paneer decreased with increase in storage period. Chewiness of lemongrass added paneer was $7.88 \pm 1.36 \mathrm{~N}$ on $0^{\text {th }}$ day, which decreased to $4.00 \pm 0.4 \mathrm{~N}$ after 23 days of storage at refrigeration temperature.

\section{Springiness}

The results indicated that the initial springiness of CP was lower than RFP (Table 3). The springiness of paneer samples decreased significantly $(\mathrm{P}<0.05)$ with increase in storage period. Fresh $\mathrm{CP}$ had springiness $6.245 \pm 0.128 \quad \mathrm{~mm}$ which decreased significantly $(\mathrm{P}<0.05)$ to $5.863 \pm 0.145 \mathrm{~mm}$ after 12 days, $5.859 \pm 0.109 \mathrm{~mm}$ after 16 days of refrigerated storage. Fresh RFP had springiness $6.654 \pm 0.112 \mathrm{~mm}$ which decreased significantly $(\mathrm{P}<0.05)$ to $6.367 \pm 0.174 \mathrm{~mm}$ after 16 days of storage at refrigerated temperature. The type of paneer showed significant $(\mathrm{P}<0.05)$ effect on springiness. The storage period showed significant $(\mathrm{P}<0.05)$ effect. The interaction between type of paneer and storage period showed non-significant (P>0.05) effect. Joseph (2016) also reported a decrease in value of lemongrass added paneer during storage. Springiness of lemongrass added paneer was $0.78 \pm 0.03$ on $0^{\text {th }}$ day, which decreased to $0.66 \pm 0.05$ after 23 days of storage at refrigeration temperature.

\section{Gumminess}

The results indicated that the initial gumminess of CP was lower than RFP (Table 3). The gumminess of paneer samples decreased significantly $(\mathrm{P}<0.05)$ with increase in storage period. Fresh $\mathrm{CP}$ had gumminess $7.194 \pm 0.611 \mathrm{~N}$ which decreased significantly $(\mathrm{P}<0.05)$ to $6.498 \pm 0.451 \mathrm{~N}$ after 12 days, $6.193 \pm 0.557 \mathrm{~N}$ after 16 days of refrigerated storage.

Fresh RFP had gumminess $8.967 \pm 0.448 \mathrm{~N}$ which decreased significantly $(\mathrm{P}<0.05)$ to $6.266 \pm 0.618 \mathrm{~N}$ after 16 days of storage at refrigerated temperature. The type of paneer showed significant $(\mathrm{P}<0.05)$ effect on gumminess. The storage period showed significant $(\mathrm{P}<0.05)$ effect. The interaction between type of paneer and storage period showed non-significant $(\mathrm{P}>0.05)$ effect.

However, no research has been reported in literature on the changes in hardness, cohesiveness, chewiness, springiness and gumminess of reduced-fat paneer prepared using GDL as an acidulant in combination with CMC during storage for comparison. 


\section{Effect of Storage Period on Microbial Quality}

The microbiological quality of the paneer depends on the bacteriological quality of the milk, the practice of hygiene during paneer production and its subsequent handling, packaging and storage. Coliforms, yeasts and molds are destroyed when milk is heated at 82 ${ }^{\circ} \mathrm{C} / 5$ min when present in raw milk. However, such microbes can contaminate the product through a various sources like air, water, equipment, knife, muslin cloth and persons handling the products (Aggarwal and Srinivasan, 1980). The SPC, Yeast and mould and Coliform count requirements as specified by FSSAI (2011) for paneer is maximum $3,50,000 / \mathrm{g}, 150 / \mathrm{g}$ and 100/g respectively. The microbiological status (viz., standard plate count, yeast and mold count, coliform count) paneer stored at refrigeration temperature is presented in Table 4.

\section{Standard plate count}

The SPC $\left(\log _{10} \mathrm{cfu} / \mathrm{g}\right)$ of CP and RFP during storage were found to increase with the increase in storage period. It can be seen from the Table 4 that SPC count of CP and RFP increased significantly $(\mathrm{P}<0.05)$ with increase the storage period. Fresh control paneer sample had a SPC count of $3.50 \pm 0.19$ $\log _{10} \mathrm{cfu} / \mathrm{g}$ which increased significantly $(\mathrm{P}<0.05)$ to $5.12 \pm 0.03 \log _{10} \mathrm{cfu} / \mathrm{g}$ after 12 days, $5.41 \pm 0.01 \log _{10} \mathrm{cfu} / \mathrm{g}$ after 16 days of refrigerated storage.

Fresh RFP had SPC count 3.33 \pm 0.21 $\log _{10} \mathrm{cfu} / \mathrm{g}$ which increased significantly $(\mathrm{P}<0.05)$ to $5.32 \pm 0.01 \log _{10} \mathrm{cfu} / \mathrm{g}$ after 16 days of storage at refrigerated temperature. The type of paneer showed significant $(\mathrm{P}<0.05)$ effect on SPC. The storage period showed significant $(\mathrm{P}<0.05)$ effect. The interaction between type of paneer and storage period showed non-significant $(\mathrm{P}>0.05)$ effect.
Gediya (2014) observed that fresh paneer sample had a SPC count of $4.29 \pm 0.08 \mathrm{log}$ cfu/g which increased significantly $(\mathrm{P} \leq 0.05)$ to $4.48 \pm 0.03 \log \mathrm{cfu} / \mathrm{g}$ after 8 days of storage and also the numbers of SPC increased but to $4.60 \pm 0.02 \mathrm{log} \mathrm{cfu} / \mathrm{g}$ after $16 \mathrm{~d}$ of storage. Joseph (2016) also observed that gradual increase in SPC during the storage period in control and experimental samples.

In case of fresh control sample SPC was $0.06 \pm 0.11 \times 10^{3} \mathrm{cfu} / \mathrm{g}$ which increased to $98.93 \pm 0.9 \times 10^{3} \mathrm{cfu} / \mathrm{g}$ on $18^{\text {th }}$ day, then slime formation occur on further storage and in case of lemongrass added samples, a slimy layer was observed on $23^{\text {rd }}$ day of storage. Roy (2016) observed that SPC present in reduced fat paneer packed in LDPE pouch and laminated pouch was initially increased from 3.23 to $6.55 \log _{10} \mathrm{cfu} / \mathrm{g}$ on $12^{\text {th }}$ day and 3.23 to $5.97 \log _{10} \mathrm{cfu} / \mathrm{g}$ on $15^{\text {th }}$ day of storage at refrigerated temperature respectively.

Patel (2014) observed that Na-sorbate added paneer had $8.25 \times 10^{3} \mathrm{cfu} / \mathrm{g}$ SPC on zero d, which increased to $1.02 \times 10^{5} \mathrm{cfu} / \mathrm{g}$ after $15 \mathrm{~d}$ of storage.

Suthar (2015) reported that increase in SPC count from initial $3.46 \log _{10} \mathrm{cfu} / \mathrm{g}$ to 3.53 $\log _{10} \mathrm{cfu} / \mathrm{g}$ after 12 days of storage at refrigerated temperature. Ranmode (2010) observed that SPC of control samples was $3.27 \mathrm{log} \mathrm{cfu} / \mathrm{g}$, which increased to $5.80 \mathrm{log}$ cfu/g on $6^{\text {th }}$ day, whereas that of the samples treated with nisin was $2.36 \mathrm{log} \mathrm{cfu} / \mathrm{g}$ which increased gradually and reached to $5.40 \mathrm{log}$ cfu/g on $12^{\text {th }}$ day of storage.

According to FSSAI requirements the microbiological criteria which separates marginally acceptable quality from unsatisfactory quality for SPC count is should not be more than 3,50,000 cfu/g. RFP met the requirements for SPC up to $16^{\text {th }}$ day of storage. 


\section{Yeast and mold count}

It can be seen from the Table 4 that $Y \& M$ count of CP and RFP increased significantly $(\mathrm{P}<0.05)$ with increase the storage period. Fresh CP had a Y\&M count nil which increased significantly $(\mathrm{P}<0.05)$ to $9.17 \pm 1.04 / \mathrm{g}$ after 12 days, $17.00 \pm 2.65 / \mathrm{g}$ after 16 days of refrigerated storage. Fresh RFP had Y\&M count nil which increased significantly $(\mathrm{P}<0.05)$ to $10.33 \pm 1.53 / \mathrm{g}$ after 16 days of storage at refrigerated temperature. The type of paneer showed significant $(\mathrm{P}<0.05)$ effect on $\mathrm{Y} \& \mathrm{M}$. The storage period showed significant $(\mathrm{P}<0.05)$ effect. The interaction between type of paneer and storage period showed significant $(\mathrm{P}<0.05)$ effect.

Gediya (2014) observed that paneer samples were found free from $\mathrm{Y} \& \mathrm{M}$ on zero $\mathrm{d}$ of storage but after $4^{\text {th }}$ day the count was found to be $0.35 \pm 0.40 \quad \log _{10} \mathrm{cfu} / \mathrm{g}$. The count increased significantly $(\mathrm{P} \leq 0.05)$ to $1.05 \pm 0.26$ after 8 days and $1.55 \pm 0.07 \log _{10} \mathrm{cfu} / \mathrm{g}$ after 16 days of refrigerated storage $\left(7 \pm 2^{\circ} \mathrm{C}\right)$. Joseph (2016) observed that the Y\&M count of control and lemongrass added samples showed a sharp increased from an initial value of $0.08 \times 10^{2} \mathrm{cfu} / \mathrm{g}$ to $9.96 \times 10^{2} \mathrm{cfu} / \mathrm{g}$ and from $0.15 \times 10^{2} \mathrm{cfu} / \mathrm{g}$ to $9.8 \times 10^{2} \mathrm{cfu} / \mathrm{g}$, respectively. Suthar (2015) reported that increase in Y\&M count from absent in zero $d$ then found 136/g after 15 days storage at refrigeration temperature. Roy (2016) observed that Y\&M count present in reduced fat paneer packed in LDPE pouch and laminated pouch was initially increased from 1.83 to $3.60 \log _{10}$ $\mathrm{cfu} / \mathrm{g}$ on $12^{\text {th }}$ day and 1.83 to $3.49 \log _{10} \mathrm{cfu} / \mathrm{g}$ on $15^{\text {th }}$ day of storage at refrigerated temperature respectively. Patel (2014) observed that Na-sorbate added paneer had 5 cfu/g Y\&M on zero day, which increased to $145 \mathrm{cfu} / \mathrm{g}$ after 15 days of storage. Ranmode (2010) observed that fresh samples of control paneer had Y\&M count $1.90 \log \mathrm{cfu} / \mathrm{g}$, which increased to $3.16 \mathrm{log} \mathrm{cfu} / \mathrm{g}$ on $6^{\text {th }}$ day of storage and paneer treated with nisin had initially $1.86 \log \mathrm{cfu} / \mathrm{g}$, which increased to $4.08 \log \mathrm{cfu} / \mathrm{g}$ on $12^{\text {th }}$ day of storage at refrigerated temperature.

According to FSSAI requirements the microbiological criterion which separates marginally acceptable quality from unsatisfactory quality for Y\&M count should not be more than $150 / \mathrm{g}$. RFP samples met this requirement up to $16^{\text {th }}$ day of storage.

\section{Coliform count}

Coliforms were found to be absent in all samples of paneer on the day of preparation and during entire storage period.

No research has been reported in literature on the changes in standard plate count, yeast and mold and coliform count of reduced-fat paneer prepared using GDL as an acidulant in combination with $\mathrm{CMC}$ during storage for comparison.

Based on the results obtained in this part of study it can be concluded that the product has shelf-life of 16 days when stored at $7 \pm 1^{\circ} \mathrm{C}$ in $12 \mu$ polyester $+50 \mu \mathrm{LD} /$ LLDPE laminated pouches under vacuum compared to 12 days for control paneer. It also met the microbial standard as per FSSAI.

Similar results observed by Gediya (2014) who reported that paneer prepared using Amla juice as coagulant can be well acceptable up to 16 days of storage at refrigeration temperature when packed in MetPolyester/Polyfilm pouches $(85 \mu \mathrm{m})$. Buch et al., (2014) reported that paneer (incorporated with $0.6 \%$ turmeric) had shelf life up to 12 days on storage at $7 \pm 1{ }^{\circ} \mathrm{C}$ in composite polyethylene terephthalate (PET)/low-density polyethylene (LDPE) film (50 $\mu$ thickness) pouch. Suthar (2015) also observed that 
vacuum packaged paneer could be stored under refrigerated $\left(5 \pm 2^{\circ} \mathrm{C}\right)$ condition for up to 15 days in polythene bag $(80 \mu \mathrm{m})$ on the other hand Joseph (2016) also reported that lemongrass flavoured paneer packed in LDPE pouches showed shelf life of 23 days at $7 \pm 2^{\circ} \mathrm{C}$.

In conclusion, reduced-fat paneer stored in 12 $\mu$ polyester $+50 \mu$ LD/LLDPE laminated pouches under vacuum. During storage there was a significant $(\mathrm{P}<0.05)$ increase in acidity, free fatty acid and tyrosine content. The hardness, springiness, chewiness and gumminess values decreased significantly $(\mathrm{P}<0.05)$ during storage. However, no significant $(\mathrm{P}>0.05)$ effect was found on cohesiveness values during storage. There was a significant $(\mathrm{P}<0.05)$ increase in $\mathrm{SPC}$ and yeast and mold count during storage. The RFP has shelf-life of 16 days and regular paneer has 12 days when stored at $7 \pm 1{ }^{\circ} \mathrm{C}$ in $12 \mu$ polyester $+50 \mu$ LD/LLDPE laminated pouches under vacuum.

\section{References}

Aneja, R.P., Mathur, B.N., Chandan, R.C., and Banerjee, A.K. 2002. Heat-acid coagulated products. In: Technology of Indian Milk Products, Dairy India Yearbook, Dairy India Publication, New Delhi, pp. 133-142.

Bhadekar, S.V., Deshmukh, B.R., Baswade, S.V., Mule, R.S., and Gatchearle, P.L. 2008. Sensory evaluation and overall acceptablility of paneer from buffalo milk added with sago powder. J. Dairy Foods Home Sci. 27(2): 99-103.

Bhattacharya, D.C., Mathur, O.N., Srinivasan, M.R., and Samlik, O. 1971. Studies on the composition of paneer. Indian $J$. Nutr. Diet. 39(12): 548-550.

Buch, S., Pinto, S., and Aparnathi, K.D. 2014. Evaluation of efficacy of turmeric as a preservative in paneer. J. Food Sci.
Technol. 51(11): 3226-3234.

FSSAI (2011). Food Safety and Standards Authority of India. Ministry of health and family welfare. Government of India.

Gediya, H.K. 2014. Evaluation of Amla juice as coagulant for the manufacture of Paneer. M.Tech. Thesis, Anand Agricultural University, Anand, India.

Guo, S., and Ono, T. 2005. The role of composition and content of protein particles in soymilk on tofu curding by glucono- $\delta$-lactone or calcium sulfate. $\mathrm{J}$. Food Sci. 70(4): 258-262.

IMARC. $2018 . \quad$ https:www. Imargroup.com/Indian-cheese-paneermarket report. Accessed on April 6, 2019.

IS: 10484. 1983. Specification for Paneer. Bureau of Indian Standards, Manak Bhavan, New Delhi.

IS: 15346. 2003. Method for Sensory Evaluation of Paneer/Chhana. Bureau of Indian Standards, Manak Bhavan, New Delhi.

IS: 5401. 1969. Methods for detection and estimation of coliform bacteria in food stuffs. Bureau of Indian Standards, Manak Bhavan, New Delhi.

IS: 5402. 1969. Method for plate count of bacteria in food stuffs. Bureau of Indian Standards, Manak Bhavan, New Delhi.

IS: 5403. 1969. Method for yeast and mold count in food stuffs. Bureau of Indian Standards, Manak Bhavan, New Delhi.

Joseph, K. 2016. Lemongrass flavoured paneer process optimization utilization and evaluation of shelf life. M.Tech. Thesis, National Dairy Research Institute (Deemed University), Bengaluru, India.

Khatkar, A.B., Ray, A., and Kaur, A. 2017. Studies on shelf life extension of Paneer with the addition of plant essential oil and different packaging materials. Int. J. Curr. Microbiol. App. 
Sci. 6(9): 376-389.

Koniecko, E.S. 1979. Handbook for Meat Chemists. Wayne, New Jersey, USA: Avery Publishing Group Inc. pp: 68-69.

Lowry, O.H., Rosebrough, N.J., Farr, A.L., and Randall, R.J. 1951. Protein measurement with the Folin phenol reagent. J. Biol. Chem. 193(1): 265-275.

Lucey, J., and Kelly, J. 1994. Cheese yield. Int. J. Dairy Technol. 47(1): 1-14.

Murtaza, M.S., Sameen, A., Huma, N., and Hussain, F. 2017. Influence of hydrocolloid gums on textural, functional and sensory properties of low fat Cheddar Cheese from buffalo milk. Pak. J. Zool., 49(1): 27-34.

Patel, R.B. 2014. Evaluation of sorbic acid and its salts as a preservative for paneer. M.Tech. Thesis, Anand Agricultural University, Anand.

Ranmode, A.K. 2010. Evaluation of efficacy of Nisin as a preservative for paneer. M.Tech. Thesis, Anand Agricultural University, Anand.
Roy, J. 2016. Quality improvement of reduced-fat paneer from cow milk. M.Tech. Thesis, Kolkata, India.

Sandrou, D.K., and Arvanitoyannis, I.S. 2003. Low-fat/calorie foods: current state and perspectives. Crit. Rev. Food Sci. Nutr. 40: 427-447.

Shendi, E.G. 2017. Investigation of using guar gum for improving of texture and rheological features of Iranian low-fat white cheese. Int. J. Adv. Manuf. Technol. 8(3): 1-5.

Suthar, J.S. 2015. Evaluating the effect of homogenization on the quality of paneer. M.Tech Thesis, Anand Agricultural University, Anand, India.

Tavakolipour, H., Matini, S., Pasdar, N., and Jalilzade, A. 2014. Monitoring the chemical and textural changes during ripening of Iranian white cheese made with different concentration of glucono delta lactone. Animal Biology and Animal Husbandry, 6(2): 181-188.

\section{How to cite this article:}

Mamata Chaudhary, Suneeta Pinto, Preeti Paul and Yashvantha, R. 2019. Shelf Life Studies of Reduced-Fat Paneer Prepared Using GDL as an Acidulant. Int.J.Curr.Microbiol.App.Sci. 8(06): 1918-1933. doi: https://doi.org/10.20546/ijcmas.2019.806.230 